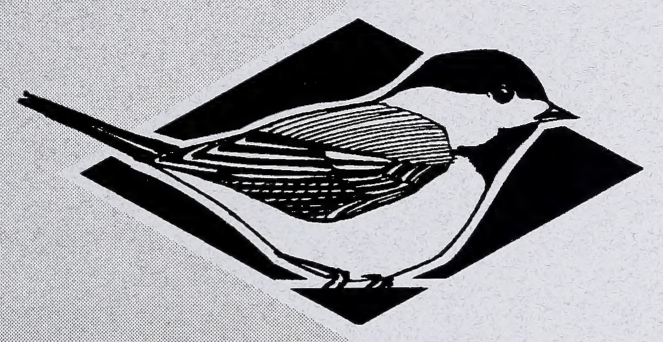

\title{
Status of the Ord's Kangaroo Rat (Dipodomys ordii) in Alberta
}

David L. Gummer

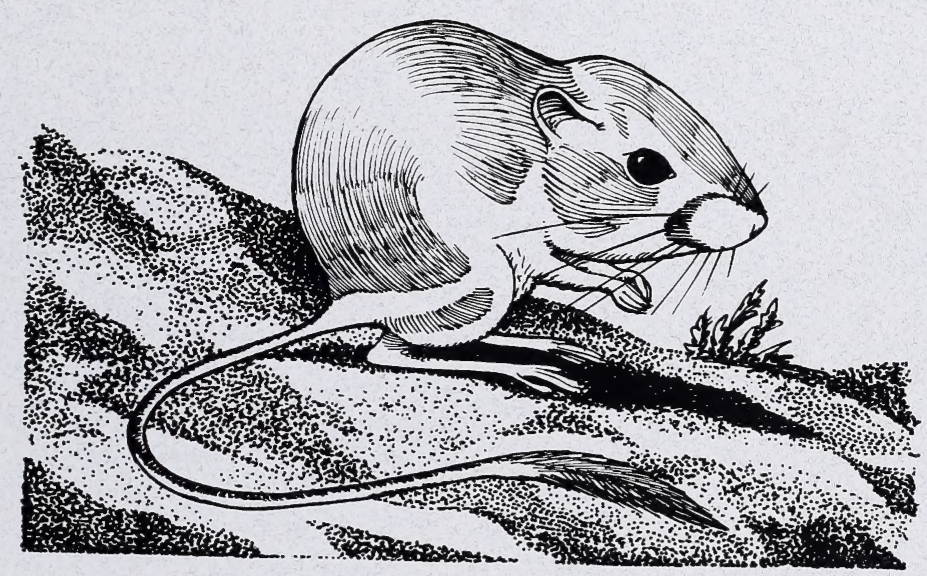

(im) 
Digitized by the Internet Archive in 2015 


\title{
Status of the Ord's Kangaroo Rat (Dipodomys ordii) in Alberta
}

\author{
David L. Gummer
}

Alberta Wildlife Status Report No. 4

Published By:

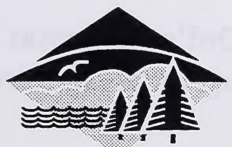


Publication No. T/365

ISBN: 0-7732-5125-1

ISSN: $1206-4912$

Series Editor: David R. C. Prescott

Illustrations: Brian Huffman

For copies of this report, contact:

Information Centre - Publications

Alberta Environmental Protection

Natural Resources Service

Main Floor, Bramalea Building

9920 - 108 Street

Edmonton, Alberta, Canada T5K 2M4

Telephone: (403) 422-2079

\section{OR}

Communications Division

Alberta Environmental Protection

\#100, 3115 - 12 Street NE

Calgary, Alberta, Canada T2E 7J2

Telephone: (403) 297-3362

This publication may be cited as:

Gummer, D. L. 1997. Ord's Kangaroo Rat (Dipodomys ordii). Alberta Environmental Protection, Wildlife Management Division, Wildlife Status Report No. 4, Edmonton, AB. $16 \mathrm{pp}$. 


\section{PREFACE}

Every five years, the Wildlife Management Division of Alberta Natural Resources Service reviews the status of wildlife species in Alberta. These overviews, which have been conducted in 1991 and 1996, assign individual species to "color" lists which reflect the perceived level of risk to populations which occur in the province. Such designations are determined from extensive consultations with professional and amateur biologists, and from a variety of readily-available sources of population data. A primary objective of these reviews is to identify species which may be considered for more detailed status determinations.

The Alberta Wildlife Status Report Series is an extension of the 1996 Status of Alberta Wildlife review process, and provides comprehensive current summaries of the biological status of selected wildlife species in Alberta. Priority is given to species that are potentially at risk in the province (Red or Blue listed), that are of uncertain status (Status Undetermined), or which are considered to be at risk at a national level by the Committee on the Status of Endangered Wildlife in Canada (COSEWIC).

Reports in this series are published and distributed by the Wildlife Management Division of Alberta Environmental Protection, and are intended to provide detailed and up-to-date information which will be useful to resource professionals for managing populations of species and their habitats in the province. The reports are also designed to provide current information which will assist the proposed Alberta Endangered Species Conservation Committee to identify species that may be formally designated as endangered or threatened under the Alberta Wildlife Act. To achieve these goals, the reports have been authored and/or reviewed by individuals with unique local expertise in the biology and management of each species. 


\section{EXECUTIVE SUMMARY}

Ord's Kangaroo Rats (Dipodomys ordii) are medium-sized, nocturnal rodents that are adapted for survival in arid environments. The species is widespread in western North America, but reaches the northern edge of its range in southeastern Alberta and southwestern Saskatchewan. There, it inhabits sparsely-vegetated habitats with loose, sandy soils. These habitats are uncommon and fragmented within the Canadian range. Ord's Kangaroo Rats are currently included on the "Blue List" of species which may be at risk in Alberta because of their localized distribution and specific habitat requirements. The species is listed by the Committee on the Status of Endangered Wildlife in Canada (COSEWIC) as "vulnerable".

In Alberta, Ord's Kangaroo Rats are known to occur only in the eastern portion of Canadian Forces Base Suffield, the Middle Sand Hills area, and along the Red Deer River at Dune Point. The species has not been found in other areas of southern Alberta that have apparently suitable habitat, but further surveys are necessary to better define the species' range in the province. Population estimates and recent trends are not known; however, they would be of limited utility for Kangaroo Rats because of the animals' typically dynamic populations. Habitat loss by vegetation encroachment has resulted from altered grazing regimes, reduced fire frequency, and other human land-use changes on the prairies. Therefore the availability of suitable habitat in Alberta is declining.

Ord's Kangaroo Rats on the Canadian prairies are isolated from southern conspecifics by at least $325 \mathrm{~km}$, and have developed unique strategies for survival at northern latitudes. Longterm isolation, restricted provincial range, and dependence on rare and unique habitats make Ord's Kangaroo Rat particularly sensitive to human activities and natural events. The species should therefore be recognized as a conservation priority in Alberta, and distribution and population surveys should be conducted so that practical management guidelines for this species can be formulated. 


\section{ACKNOWLEDGEMENTS}

The Alberta Natural Resources Service, Canadian Wildlife Service, Committee On the Status of Endangered Wildlife In Canada, Provincial Museum of Alberta, Royal Saskatchewan Museum, Saskatchewan Conservation Data Centre, University of Alberta Museum of Zoology, and U.S. Fish and Wildlife Service provided information regarding Kangaroo Rats in various jurisdictions. I thank S. Brechtel and J. Taggart (Alberta Natural Resources Service) for information about the present status of Kangaroo Rats in Alberta. D. Prescott (Alberta Natural Resources Service) and R. Barclay (University of Calgary) arranged for this report to be written. D. Baron (Royal Saskatchewan Museum) and H. Bryant (Provincial Museum of Alberta) provided information about museum records. W. Gummer assisted with the distribution maps and K. Gummer edited the manuscript. D. Prescott, S. Brechtel, H. Bryant, and H. Reynolds (Canadian Wildlife Service) provided useful comments on earlier drafts of the report. Recent research on the ecology and behaviour of northern Ord's Kangaroo Rats has been supported by the Alberta Challenge Grants in Biodiversity, Canadian Wildlife Service (Prairie and Northern Region), Department of National Defence (Canadian Forces Base Suffield), Natural Sciences and Engineering Research Council of Canada, University of Calgary, University of Regina, and World Wildlife Fund. I also thank J. Horb for producing the maps, and D. Ryerson (Alberta Natural Resources Service) for editorial assistance.

Production of this report was funded by the Wildlife Management Enhancement Fund of Alberta Natural Resources Service and the Alberta Conservation Association. 


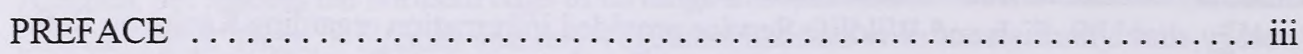
EXECUTIVE SUMMARY $\ldots \ldots \ldots \ldots \ldots \ldots \ldots \ldots \ldots \ldots \ldots \ldots \ldots \ldots \ldots$ iv

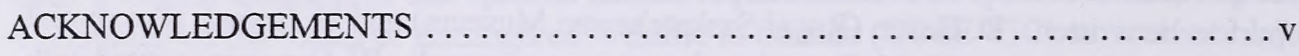
INTRODUCTION $\ldots \ldots \ldots \ldots \ldots \ldots \ldots \ldots \ldots \ldots \ldots \ldots \ldots \ldots \ldots \ldots \ldots \ldots \ldots \ldots$

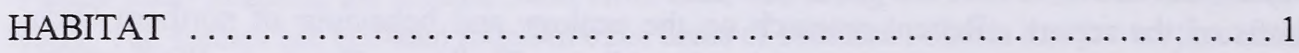

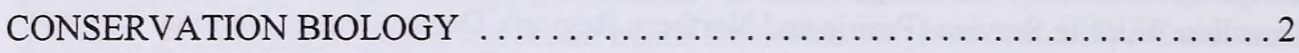

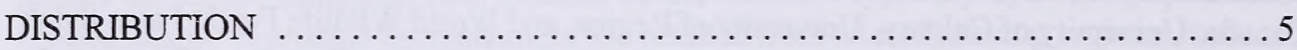

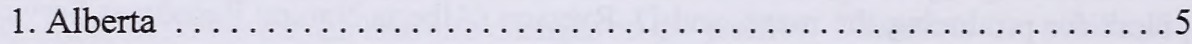

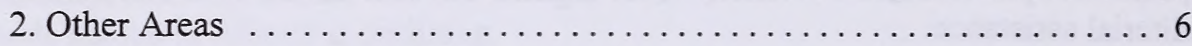

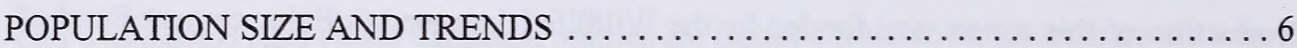

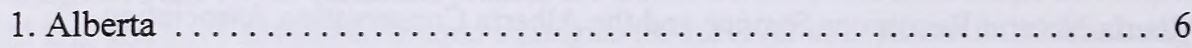

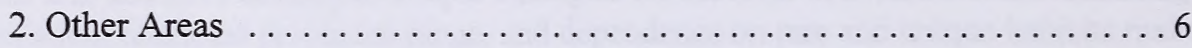

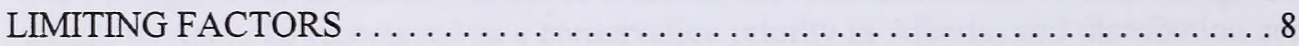

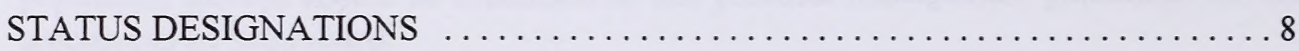

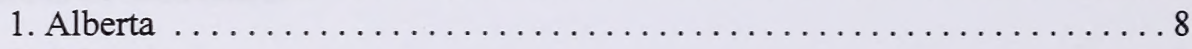

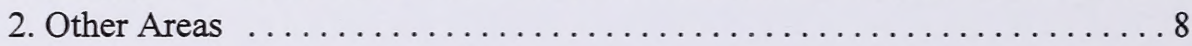

RECENT MANAGEMENT IN ALBERTA $\ldots \ldots \ldots \ldots \ldots \ldots \ldots \ldots \ldots \ldots$

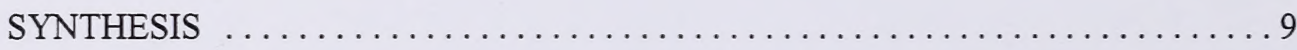

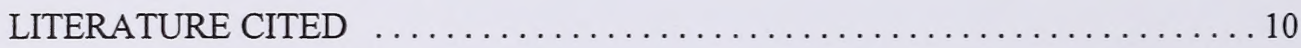

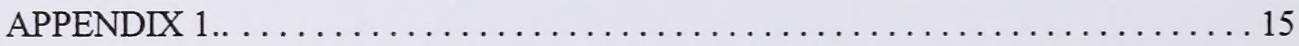

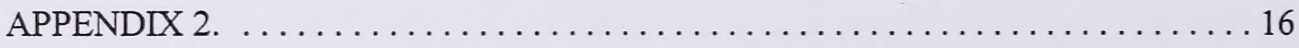




\section{INTRODUCTION}

Ord's Kangaroo Rats (Dipodomys ordii) are common and widespread in the United States and Mexico. In Canada, the species occurs in the sand hill areas of southeastern Alberta and southwestern Saskatchewan. Kangaroo Rats are included on the "Blue List*" of species that may be at risk in Alberta because of their unique habitat requirements and localized occurrence in the province (Alberta Wildlife Management Division 1996). The Committee On the Status of Endangered Wildlife In Canada (COSEWIC) currently considers Ord's Kangaroo Rats to be "vulnerable" (Gummer 1995).

The biology of Ord's Kangaroo Rat has been studied extensively across most of the species' range; however, the northern population of Ord's Kangaroo Rats has only recently become the focus of scientific investigation. The purpose of this report is to review and summarize the information presently available regarding Ord's Kangaroo Rats and their status in Alberta.

\section{HABITAT}

The Ord's Kangaroo Rat occurs in arid grassland and open scrubland environments with sparse vegetation and sandy soils (Armstrong 1979, Hallett 1982, Maxwell and Brown 1968). Kangaroo Rats prefer habitats that provide smooth, sparsely-vegetated substrates with workable soils because of their bipedal locomotion, fossorial nature, and medium body size (Bartholomew and Caswell 1951, Hallett 1982, Maxwell and Brown 1968). Accordingly, Kenny (1989) reported that Kangaroo Rats in Saskatchewan were almost exclusively associated with actively eroding sand dune complexes.

Active sand dunes are important natural habitat for Kangaroo Rats; however, eroding sand dunes are becoming rare in Alberta and Saskatchewan because of gradual climate change and human-induced changes in the landscape (Epp and Townley-Smith 1980). Smith and Hampson (1969) first reported Kangaroo Rats occupying a right-of-way in southeastern Alberta. In recent years, Kangaroo Rats have been found to be abundant on roads, fireguards, and other human-disturbed areas proximate to sand hills in southeastern Alberta (D. Gummer, unpubl. data). Stangl et al. (1992) suggested that disturbance of prairie by cattle, shrub control, and vehicle traffic provided habitat for Texas Kangaroo Rats (D. elator) and they suggested that human disturbance might partially replicate past landscaping effects of prairie fires, Bison (Bison bison), and Prairie Dog (Cynomys ludovicianus) colonies. Similarly, roads appear to increase the connectance of small, local populations of "endangered" Stephens' Kangaroo Rats (‥ stephensi) in the United States and thus the roads are expected to increase the persistence of the populations (Price et al. 1994). Further, Merriam's Kangaroo Rats (D. merriami) are abundant in heavily-grazed pastures of Arizona, and Reynolds (1958) proposed that decreased stubble height and density

* See Appendix 1 for definitions of selected status designations. 
of grasses made the disturbed habitat more favorable for Kangaroo Rat locomotion and burrowing.

Smith and Hampson (1969) indicated that Kangaroo Rats in southeastern Alberta did not show affinity for particular vegetation communities. In contrast, lance-leaved psoralea (Psoralea lanceolata) and Wood's rose (Rosa woodsii) appeared to dominate the vegetation communities in which Kangaroo Rats were found in Saskatchewan (Baron 1979, Nero and Fyfe 1956). In the United States, Ord's Kangaroo Rats occur in association with greasewood (Sarcobatus spp.; Feldhamer 1979), juniper (Juniperus spp.; Allred 1973), mesquite (Prosopsis spp; Best and Hoditschek 1986), sage brush (Artemisia spp.; Rogers and Hedlund 1980), saltbush (Atriplex spp; Honeycutt et al. 1981), shinnery oak (Quercus spp.; Best and Hoditschek 1986, Dice 1930, Garner 1974) and yucca (Yucca spp.; Maxwell and Brown 1968).

\section{CONSERVATION BIOLOGY}

Ord's Kangaroo Rat is a member of the family Heteromyidae, a group of New World rodents that is recognized for inhabiting extremely arid environments (French 1993, Garrison and Best 1990). There are 24 species of Kangaroo Rat (Dipodomys spp.), of which Ord's Kangaroo Rat appears to be the most common and widespread (Garrison and Best 1990). Ord's Kangaroo Rats are medium-sized rodents with orange-brown dorsal pelage and white ventral fur (Banfield 1981, Garrison and Best 1990), five toes on each foot, large eyes, and particularly long tails (Hall 1981, Soper 1964). The species' large hind limbs and feet facilitate the bipedal, hopping-style of locomotion for which Kangaroo Rats are named (Setzer 1949).

Ord's Kangaroo Rats are mainly granivorous (Best and Hoditschek 1982, Garrison and Best 1990) and collect food items and nest material in their external, fur-lined cheek pouches (Soper 1964). Kangaroo Rats meet their daily energy requirements with one maximum cheek pouch load of seeds (Morton et al. 1980). Kangaroo Rats are entirely nocturnal, highly fossorial, and cache their food underground in complex burrow systems (Kenagy 1976).

Kangaroo Rats are desert animals. Accordingly, they are adapted for water conservation (French 1993) and can survive almost independent of exogenous water (French 1993, Schmidt-Nielson 1964). Water conservation is achieved mainly by physiological and behavioural abilities to reduce water loss (French 1993, Hinds and MacMillen 1985). For example, Ord's Kangaroo Rats produce highly concentrated urine (Fairbanks et al. 1983). Similarly, Kangaroo Rats have the most concentrated milk of the terrestrial mammals (Kooyman 1963). The nasal passages of Kangaroo Rats are convoluted to facilitate counter-current heat exchange and promote condensation of moisture, thereby minimizing respiratory water loss (Collins et al. 1971, Jackson and Schmidt-Nielson 1964).

Adult Ord's Kangaroo Rats in Saskatchewan had an average mass of 
$70.7 \mathrm{~g}$ (range $=60$ to $86.5 \mathrm{~g}$; Kenny 1989), compared to an average of $52 \mathrm{~g}$ reported for adults elsewhere in the species' range (Jones 1985). Ord's Kangaroo Rats are sexually dimorphic such that males tend to be larger than females (Best 1993, Desha 1967, Kennedy and Schnell 1978). Males are also the more abundant and active gender (Garrison and Best 1990).

Ord's Kangaroo Rats are not colonial; rather, they are solitary and highly territorial (Eisenberg 1963). Individuals aggressively defend their burrows, food caches, and surrounding areas from intruding conspecifics and other rodents (Bartholomew and Caswell 1951, Daly et al. 1984, Eisenberg 1963, Garner 1974). The misnomer "Kangaroo Rat colony" (see Nero and Fyfe 1956, Smith and Hampson 1969) arose because of the tendency for individual Kangaroo Rats to excavate large numbers of conspicuous burrows. Recent Kangaroo Rat activity can be confirmed by the presence of active burrows and tracks, which are characterized by freshly dug soil, paired footprints, and long tail marks in the soil (Epp and Waker 1980, Nero and Fyfe 1956). Further, individuals often leave clipped vegetation as evidence of recent foraging and long-term inhabitation by Kangaroo Rats is evidenced by runways worn into the surrounding vegetation and soil (D. Gummer, unpubl. data).

Kangaroo Rats have dynamic populations because of variable rates of survival and reproduction. Individuals are capable of reproduction during the entire year if conditions are favorable (Hoditschek and Best 1983); however, there are generally only one or two breeding cycles each year
(Flake 1974, Johnston 1956). The onset of reproduction appears to be related to precipitation, food availability, and population density (McCulloch and Inglis 1961). Age of first reproduction is approximately 83 days (Jones 1985) and the average number of embryos per female was 3.5 in Nevada (range $=1$ to 6 , Hall 1946) and 2.4 in New Mexico (range $=2$ to 3, Johnston 1956). The number of embryos per female appears to be positively correlated with precipitation (Best and Hoditschek 1986). Gestation is approximately 30 days (Day et al. 1956, Duke 1944) and individual females can have two litters during the same year (Johnston 1956). Captive Kangaroo Rats have lived as long as seven years and five months (Egoscue et al. 1970); however, free-ranging Kangaroo Rats in Alberta appear to have very low annual survival (<10\%; D. Gummer, unpubl. data).

Kangaroo Rats and Olive-backed Pocket Mice (Perognathus fasciatus) are the only Heteromyid rodents found in Alberta. Other small rodents that occur sympatric with Kangaroo Rats in Alberta include Deer Mice (Peromyscus maniculatus), Meadow Voles (Mictrotus pennsylvanicus), Northern Grasshopper Mice (Onychomys leucogaster), Sagebrush Voles (Lagarus curtatus), Western Harvest Mice (Reithrodontomys megalotis), Thirteen-lined Ground Squirrels (Spermophilus tridecemlineatus), and Northern Pocket Gophers (Thomomys talpoides; Smith 1993; H. Reynolds, unpubl. data). Most importantly, Ord's Kangaroo Rats in Alberta are not sympatric with other species of Kangaroo Rat, and therefore interspecific competition and resource 
partitioning should be less significant than elsewhere in the species' range.

The behaviour and morphology of Kangaroo Rats appear to be driven by predation. During relatively bright nighttime conditions (e.g., moonlight), above ground activity is either minimal or microhabitat-use shifts to areas with greater cover (D. Gummer, unpubl. data, Kaufman and Kaufman 1982, O'Farrell 1974, Rosenzweig 1974), presumably to reduce detection by visually-oriented predators. Also, the structure of the middle ear appears to be an adaptation for predator detection as it is most sensitive to low frequency sound (Webster and Webster 1975). Erratic bipedal movement should aid in predator avoidance, because this style of locomotion favors energy efficient retreat across open ground to the safety of burrows (Bartholomew and Caswell 1951, Yousef et al. 1970). Bipedal locomotion and enlarged auditory bullae of Kangaroo Rats appear to reduce predation compared to other sympatric rodents (Kotler 1985). Bannertail Kangaroo Rats (Dipodomys spectabilis) footdrum as an anti-predator alarm signal (Randall and Stevens 1987). Ord's Kangaroo Rats might also footdrum and this is an important behaviour because footdrumming alerts snakes that they have been detected, and causes them to retreat rather than investigate (Randall and Stevens 1987).

Despite the extent to which Kangaroo Rats have evolved anti-predator strategies, Ord's Kangaroo Rats are important prey for many raptors, reptiles, and mammals, some of which are considered to be at risk in Alberta. Potential predators in Alberta include Burrowing Owls (Speotyto cunicularia), Great Horned Owls (Bubo virginianus), Long-eared Owls (Asio otus), Short-eared Owls (ㅅ․ flammeus), Snowy Owls (Nyctea scandiaca), Bull Snakes (Pituophis melanoleucus), Prairie Rattlesnakes (Crotalus v. viridis), Badgers (Taxidea taxus), Bobcats (Felis rufus), Coyotes (Canis latrans), Least Weasels (Mustela nivalis), Long-tailed Weasels (M. frenata), Red Foxes (Vulpes vulpes), and Swift Foxes (V. velox; Smith 1993; D. Gummer, unpubl. data). Direct evidence of predation on Kangaroo Rats in Alberta is limited to observations of Burrowing Owls and Great Horned Owls hunting, striking, and carrying Kangaroo Rats, observations of Badgers digging at Kangaroo Rat burrows, and the remains of a Kangaroo Rat found inside a road-killed Prairie Rattlesnake (D. Gummer, unpubl. data).

The northern population of Ord's Kangaroo Rat appears to have been geographically isolated from southern conspecifics since the Post-Wisconsinian Hypsithermal Interval, approximately 5000 years ago (Kenny 1989). Northern Kangaroo Rats exist in a more harsh climate than southern conspecifics and may have evolved unique strategies for survival on the northern plains (Gummer 1995). For example, Kangaroo Rats remain active throughout the winter in the United States (Jorgensen and Hayward 1965, Kenagy 1976). O'Farrell (1974) found that southern Kangaroo Rats were active on the ground surface at night if there was sparse snow ( $<40 \%$ ground cover) and if the ambient temperature was greater than $-11^{\circ} \mathrm{C}$. Otherwise, Kangaroo Rats stayed in their burrows and fed on 
underground food stores. Northern Kangaroo Rats may have evolved the physiological ability to use torpor or hibernate during the winter to conserve energy when continuous snow and cold temperatures limit foraging opportunities (Gummer 1995, Kenny 1989, O'Farrell 1974).

\section{DISTRIBUTION}

1. Alberta. - Kangaroo Rats in Alberta are at the northern edge of the species' range, in restricted areas, and are geographically isolated from southern conspecifics (Figures 1 and 2; Gummer 1995, Kenny
1989). The established distribution of Kangaroo Rats in Alberta includes the eastern portion of Canadian Forces Base Suffield, the Middle Sand Hills area, and along the Red Deer River at Dune Point (Gummer 1995, Kenny 1989, Reynolds and Armbruster 1971, Smith 1972, 1993 , Smith and Hampson 1969, Soper 1964, Stevens 1972, Wallis and Wershler 1988). A limited number of field investigations outside of these areas have not revealed additional records of Kangaroo Rats. Kenny (1989) surveyed Dinosaur Provincial Park, the Lake Newell sand hills, the Pakowki Lake sand dunes, and the sand hills near Brooks, and reported

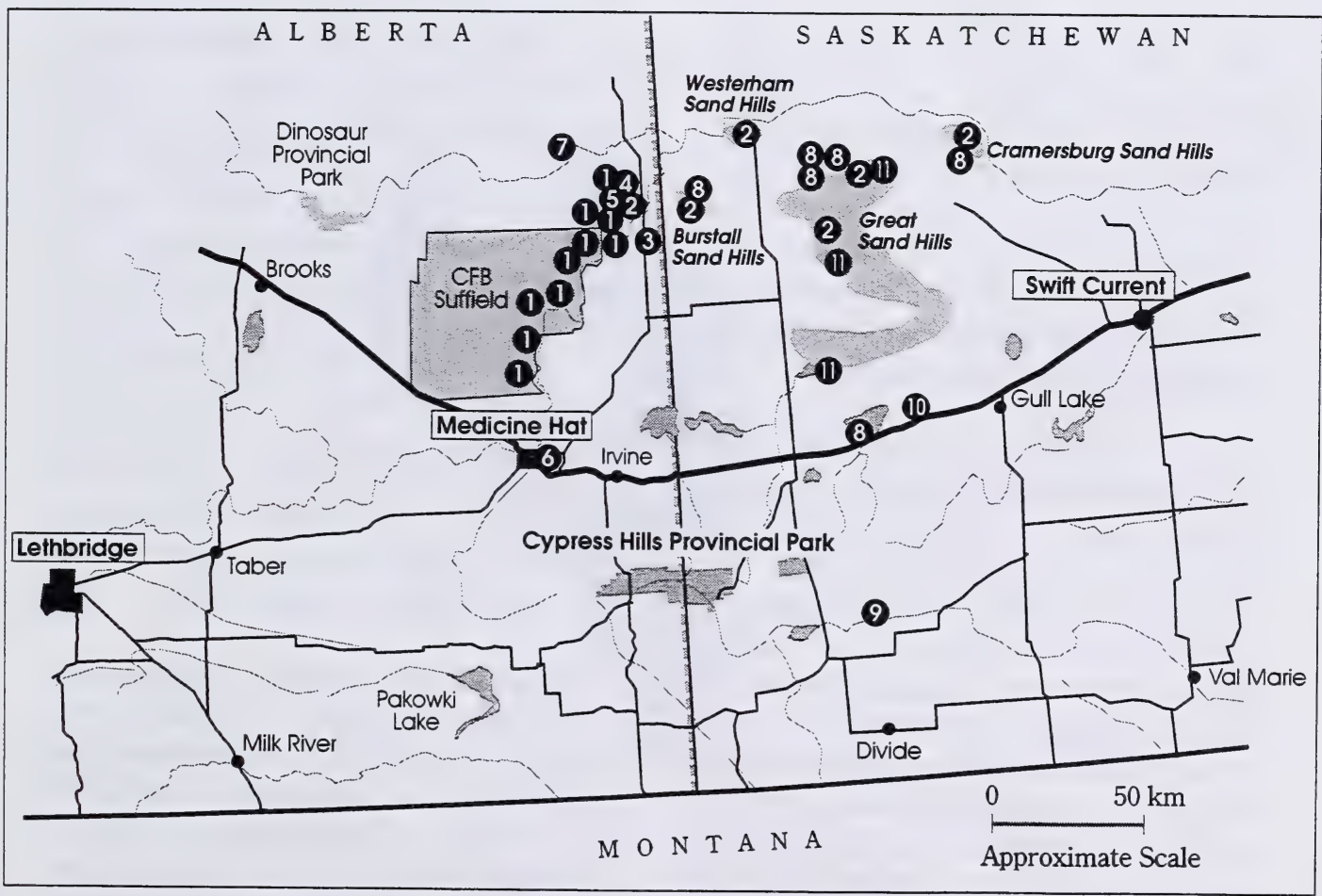

Figure 1. Locations of Ord's Kangaroo Rat observations in Alberta and Saskatchewan (modified from Gummer 1995). Numbers refer to sources listed in Appendix 2. 
that there was no evidence of Kangaroo Rats in those areas. The Milk River region might also support Kangaroo Rats (Smith and Hampson 1969), but Soper (1964) found no evidence of them there.

The distribution of Kangaroo Rats in Alberta requires careful investigation in order to determine if the provincial distribution is as localized as current records suggest. Because of Kangaroo Rats' inconspicuous size and nocturnal activity periods, the species' provincial range may be more extensive than our records indicate.

\section{Other Areas. - Kangaroo Rats occur in} the sand hills of southwestern Saskatchewan (Figures 1 and 2; Anderson 1946, Baron 1979, Epp and Waker 1980, Kenny 1989, Nero 1956, Nero and Fyfe 1956). There is also one report of a Kangaroo Rat observed in a coulee near Ravenscrag, SK (Carleton 1956), although the record is inconsistent with the species' typical association with sand hills.

Ord's Kangaroo Rat is distributed as far south as central Mexico, and occurs in the United States between Oregon and Oklahoma. Southeastern Alberta and southwestern Saskatchewan represent the northern extent of the species' range. Figure 2 shows the recognized distribution of Ord's Kangaroo Rat (after Hall 1981). However, the general range map does not reflect the geographic isolation of the northern population. The nearest population of Ord's Kangaroo Rats in Montana (38 km north of Roundup; Hall 1981 ) is approximately $400 \mathrm{~km}$ from the nearest Kangaroo Rat record in Alberta,
$325 \mathrm{~km}$ from the somewhat questionable observation at Ravenscrag, SK (Carleton 1956), and $375 \mathrm{~km}$ from the nearest Kangaroo Rat specimen collection locality (Piapot, SK; Royal Saskatchewan Museum, unpubl. data).

\section{POPULATION SIZE AND TRENDS}

1. Alberta. - Estimates of population size and trend are of limited utility for animals such as Kangaroo Rats, which have dynamic populations due to highly variable rates of survival and reproduction. Regardless, there are no documented population estimates for Kangaroo Rats in Alberta. Between 1994 and 1997, an intense capture/recapture study of Kangaroo Rats resulted in 1035 individual Kangaroo Rats marked with ear tags and a total of 2640 Kangaroo Rat observation records for Canadian Forces Base Suffield and adjacent areas. The estimated size of the study population was approximately 3000 individuals of all age and sex classes in 1995 (upper and lower confidence limts of 4160 and 2180 individuals, respectively); however, the Kangaroo Rat population needs to be considered in the context of extremely poor over-winter survival (range $=$ four to $12 \%$; D. Gummer, unpubl. data).

2. Other Areas. - Kenny (1989) captured 150 Kangaroo Rats in Saskatchewan during 1984 and 1985 . He estimated that 1370 Kangaroo Rats should occur in the sand hills of Saskatchewan, with an average density of 2.2 individuals/ha (Kenny 1989). This density is much lower than the average of 15.6 individuals/ha reported in Texas (Garner 1974) and the 


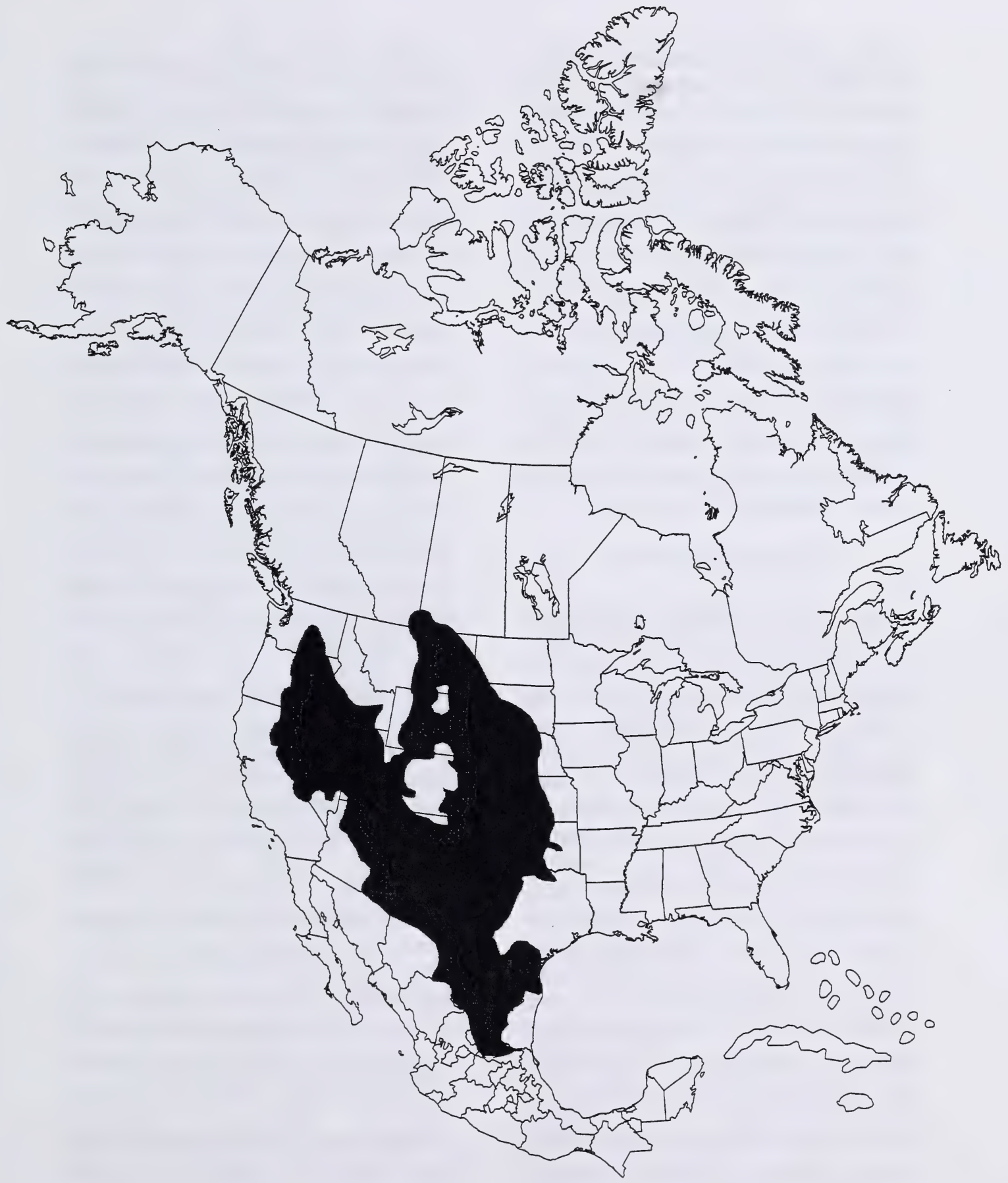

Figure 2. The distribution of the Ord's Kangaroo Rat (modified from Hall 1981). 
maximum of 53 individuals/ha reported for other areas of the United States (Conley et al. 1977). Kenny (1989) suggested that the population density in Saskatchewan was low during his study because of ongoing drought. However, Kangaroo Rats are desert animals and can exist almost independent of water. Even during drought, the northernmost Kangaroo Rats should encounter more moisture than southern conspecifics ever do. The conclusion that northern Kangaroo Rats were negatively affected by drought was not substantiated and therefore drought should not be considered an important factor for northern Kangaroo Rats.

\section{LIMITING FACTORS}

In Alberta, Ord's Kangaroo Rats appear to be limited by the availability of their preferred habitat, sparsely-vegetated sand. This habitat is available mainly in the sand hill areas of southeastern Alberta. Over time, eroding sand slowly stabilizes due to encroachment of vegetation. This encroachment occurs naturally in response to climate change, but has historically been counterbalanced by natural disturbance from fires and Bison which made sandy areas prone to erosion (Daubenmire 1968, Wright and Bailey 1982). With the suppression of fire and change in grazing regimes since human settlement, there has been little natural disturbance of prairie communities (Epp and Townley-Smith 1980). Additionally, erosion is discouraged along roadways and agricultural land. For example, hay bales are often placed over eroding sand so as to rapidly increase deep-rooting vegetative cover. Collectively, these practices have probably accelerated vegetation encroachment in recent years, and decreased the amount of natural habitat available to Kangaroo Rats (Gummer 1995, Kenny 1989).

When preferred habitat is unavailable, Kangaroo Rats occupy alternative, sparsely-vegetated habitats such as roads, trails, fireguards, fallow cropland, and intensely-grazed pastures (Kenny 1989, Price et al. 1994, Reynolds 1958, Stangl et al. 1992, D. Gummer, unpubl. data). The consequences of occupying alternative habitats have not been determined. Implications may include increased mortality and susceptibility to parasitism. Notably, large Botfly larvae (Cuterebra polita) infest approximately one third of Kangaroo Rats in southeastern Alberta and do not parasitize Kangaroo Rats elsewhere (Gummer et. al. In press)

\section{STATUS DESIGNATIONS}

1. Alberta. - The Alberta Wildlife Act lists Ord's Kangaroo Rats as "non-game animals", meaning that it is illegal to capture or kill Kangaroo Rats without appropriate permits. In two recent reviews, Ord's Kangaroo Rats were included on the "Blue List" of species which may be at risk in the province (Alberta Fish and Wildlife 1991, Alberta Wildlife Management Division 1996), due to their apparently limited distribution in Alberta and the species' dependence on sparsely-vegetated, sandy habitats.

2. Other Areas. - Ord's Kangaroo Rats are the only species of Kangaroo Rat that occur in Canada, and they exist in Canada at the northern edge of their range and in 
restricted areas. The northern population appears to be ecologically distinct from southern populations because of long term geographic isolation. Consequently, the Committee on the Status of Endangered Wildlife in Canada (COSEWIC) considers Ord's Kangaroo Rats to be "vulnerable" in Canada (Gummer 1995). Similarly, the Saskatchewan Conservation Data Centre considers Ord's Kangaroo Rats in Saskatchewan as "imperiled in the province because of rarity" (Saskatchewan Conservation Data Centre 1994).

Ord's Kangaroo Rats are common in many areas of the western United States and Mexico, and therefore are not recognized as a conservation priority in those areas. In contrast, other species of Kangaroo Rats are recognized as "endangered" in the United States because they occur in very small areas of California in which there has been substantial human development (U. S. Fish and Wildlife Service 1997). These species include the Fresno (ㅁ. nitratoides exilis), Tipton (D. ‥ nitratoides), Giant (D. ingens), Morro Bay (D. heermanni morroensis), and Stephens' (D. stephensi) Kangaroo Rats.

\section{RECENT MANAGEMENT IN ALBERTA}

Until recently, Ord's Kangaroo Rats received little attention in terms of wildlife research and management in Alberta. Between 1994 and 1997, Kangaroo Rat research has been conducted in and adjacent to Canadian Forces Base Suffield. The main objectives of the ongoing research include:

(1) characterizing the survival and reproduction of northern Kangaroo Rats; (2) determining the winter strategies of northern Kangaroo Rats; (3) examining the distribution and abundance of Kangaroo Rats in Canadian Forces Base Suffield; and (4) detailing management considerations for the species in Canadian Forces Base Suffield. Preliminary results indicate that northern Kangaroo Rats have diverged substantially from southern conspecifics, apparently as a consequence of latitude and long-term geographic isolation (D. Gummer, unpubl. data). The study will be completed during 1997 and the results should aid in the adoption of appropriate management guidelines for Ord's Kangaroo Rats in Alberta.

\section{SYNTHESIS}

Ord's Kangaroo Rats occur at the northern edge of their range in Alberta, and have been found in only a small part of the province. The northern population has been geographically isolated from southern conspecifics for approximately 5000 years. Because of the nature of their distribution, their dependence on rare, sparsely-vegetated, sandy habitat, and the ecological distinctness of the northern population, Kangaroo Rats in Alberta are of special concern and should be recognized as being particularly sensitive to human activities and natural events. The results of ongoing research on Kangaroo Rats at Canadian Forces Base Suffield will provide important information regarding the ecology of Kangaroo Rats in Alberta; however, the provincial distribution of the species must be examined by field surveys before management guidelines can be realized. 


\section{LITERATURE CITED}

Alberta Fish and Wildlife. 1985. A policy for the management of threatened wildlife in Alberta. Alberta Fish and Wildlife, Edmonton, AB. 34 pp.

Alberta Fish and Wildlife. 1991. The status of Alberta wildlife. Alberta Natural Resources Service, Edmonton, AB. 49 pp.

Alberta Wildlife Management Division. 1996. The status of Alberta wildlife. Alberta Natural Resources Service, Edmonton, AB. 44 pp.

Allred, D. M. 1973. Small mammals of the National Reactor Testing Station, Idaho. Great Basin Natur. 33: 246-250.

Anderson, R. M. 1946. Catalogue of Canadian recent mammals. Nat. Mus. Canada, Bull. No. 102, Biol. Series 31.

Armstrong, D. M. 1979. Ecological distribution of rodents in Canyonlands National Park, Utah. Great Basin Natur. 39: 199-205.

Banfield, A. W. F. 1981. The mammals of Canada. University of Toronto Press, Toronto, ON. 438 pp.

Baron, D. 1979. Evidence of Kangaroo Rats near Burstall, Saskatchewan. Blue Jay 37: 240.

Bartholomew, G. A., and H. H. Caswell. 1951. Locomotion in Kangaroo Rats and its adaptive significance. J. Mammal. 32: 155-169.
Best, T. L. 1993. Patterns of morphologic and morphometric variation in Heteromyid rodents. Pp. 197-235 in Biology of the Heteromyidae $(\mathrm{H}$. $\mathrm{H}$. Genoways and J. H. Brown, eds). Spec. Publ. No. 10, American Society of Mammalogists, Provo, UT. 719 pp.

Best, T. L., and B. Hoditschek. 1982. Analysis of cheek pouch contents of Ord's Kangaroo Rat (Dipodomys ordii). Southwest. Natur. 27: 117-119.

Best, T. L., and B. Hoditschek. 1986. Relationships between environmental variation and the reproductive biology of Ord's Kangaroo Rat (Dipodomys ordii). Mammalia 50: 173-183.

Carleton, R. R. 1956. Kangaroo Rat. Blue Jay 14: 100 .

Collins, J. C., T. C. Pilkington, and K. Schmidt-Nielson. 1971. A model of respiratory heat transfer in a small mammal. Biophys. J. 11: 886-914.

Conley, W., J. D. Nichols, and A. R. Tipton. 1977. Reproductive strategies in desert rodents. Pp. 193-215 in Transactions of the symposium on the biological resources of the Chihuahuan Desert region United States and Mexico. (R. H. Wauer and D. Riskind, eds). U. S. Department of the Interior, National Park Service, Transactions and Proceedings Series 3: 1-658.

COSEWIC. 1996. Canadian species at risk. Committee on the Status of Endangered Wildlife in Canada, Ottawa, ON. 18 pp. 
Daly, M., M. I. Wilson, and P. Behrends. 1984. Breeding of captive Kangaroo Rats, Dipodomys merriami and D. microps. J. Mammal. 65: 338-341.

Daubenmire, R. 1968. Ecology of fire in grasslands. Adv. Ecol. Research 5:209-266.

Day, B. N., H. J. Egoscue, and A. M. Woodbury. 1956. Ord's Kangaroo Rat in captivity. Science 124: 485-486.

Desha, P. G. 1967. Variation in a population of Kangaroo Rats, Dipodomys ordii medius (Rodentia: Heteromyidae) from the high plains of Texas. Southwest. Natur. 12: 275-289.

Dice, L. R. 1930. Mammal distribution in the Alamogordo region, New Mexico. University of Michigan, Museum of Zoology, Occasional Paper 213: 1-32.

Duke, K. L. 1944. The breeding season of two species of Dipodomys. J. Mammal. 25: 155-160.

Egoscue, H. J., J. G. Bittmenn, and J. A. Petrovich. 1970. Some fecundity and longevity records for captive small mammals. J. Mammal. 51: 622-623.

Eisenberg, J. F. 1963. The behavior of Heteromyid rodents. Univ. Calif. Publ. Zool. 69: 1-100.

Epp, H. T., and L. Townley-Smith. 1980. The Great Sand Hills of Saskatchewan. Saskatchewan Dept. of the Environment, Regina, SK. 156 pp.

Epp, H. T., and B. D. Waker. 1980.
Terrestrial vertebrate fauna of the Great Sand Hills. Pp. 75-88 in The Great Sand Hills of Saskatchewan (H. T. Epp and L. Townley-Smith, eds.). Saskatchewan Dept. of the Environment, Regina, SK. 156 pp.

Fairbanks, W. S., D. Greegor, L. Staudinger, and E. Bitterbaum. 1983. Water conservation of the Kangaroo Rat, Dipodomys ordii. Trans. Nebraska Acad. Sci. 11: 27-30.

Feldhamer, G. A. 1979. Vegetative and edaphic factors affecting abundance and distribution of small mammals in southeast Oregon. Great Basin Natur. 39: 207-218.

Flake, L. D. 1974. Reproduction of four rodent species in a short-grass prairie of Colorado. J. Mammal. 55: 213-216.

French, A. R. 1993. Physiological ecology of the Heteromyidae: economics of energy and water utilization. Pp 509-538 in Biology of the Heteromyidae $(\mathrm{H}$. H. Genoways and J. H. Brown, eds). Spec. Publ. No 10, American Society of Mammalogists, Provo, UT. 719 pp.

Garner, H. W. 1974. Population dynamics, reproduction, and activities of the Kangaroo Rat, Dipodomys ordii, in western Texas. Graduate Studies, Texas Tech University 7: 1-28.

Garrison, T. E. and T. L. Best. 1990. Dipodomys ordii. Mammalian Species No. 353. American Society of Mammalogists. Provo, UT. 10 pp. 
Gummer, D. L. 1995. Status report on the Ord's Kangaroo Rat, Dipodomys ordii, in Canada. Committee On the Status of Endangered Wildlife In Canada, Ottawa, ON. 25 pp.

Gummer, D. L., M. R. Forbes, D. J. Bender, and R. M. R. Barclay. Botfly (Diptera: Oestridae) Parasitism of Ord's Kangaroo Rats (Dipodomys ordii) at Suffield National Wildlife Area, Alberta, Canada. J. Parasit. In press.

Hall, E. R. 1946. Mammals of Nevada. University of California Press, Berkley, CA. 710 pp.

Hall, E. R. 1981. The mammals of North America, 2nd edn. John Wiley and Sons,. New York, NY. 600 pp.

Hallett, J. G. 1982. Habitat selection and the community matrix of a desert small-mammal fauna. Ecology 63: 1400-1410.

Hinds, D. S., and R. E. MacMillen. 1985. Scaling of energy metabolism and evaporative water loss in Heteromyid rodents. Physiol. Zool. 58: 282-298.

Hoditschek, B., and T. L. Best. 1983. Reproductive biology of Ord's Kangaroo Rat (Dipodomys ordii) in Oklahoma. J. Mammal. 64: 121-127.

Honeycutt, R. L., M. P. Moulton, J. R. Ropp, and L. Fifield. 1981. The influence of topography and vegetation on the distribution of small mammals in southwestern Utah. Southwest. Natur. 26: 295-300.
Jackson, D. C., and K. Schmidt-Nielson. 1964. Countercurrent heat exchange in the respiratory passages. Proc. Natl. Acad. Sci. 51: 1192-1197.

Johnston, R. F. 1956. Breeding of the Ord Kangaroo Rat (Dipodomys ordii) in southern New Mexico. Southwest. Natur. 1: 190-193.

Jones, W. T. 1985. Body size and life-history variables in Heteromyids. J. Mammal. 66: 128-132.

Jorgensen, C. D., and C. L. Hayward. 1965. Mammals of the Nevada Test Site. Brigham Young University Science Bulletin, Biological Series 6: 1-81.

Kaufman, D. W., and G. A. Kaufman. 1982. Effect of moonlight on activity and microhabitat use by Ord's Kangaroo Rat (Dipodomys ordii). J. Mammal. 63: 309-312.

Kenagy, G. J. 1976. The periodicity of daily activity and its seasonal changes in free-ranging and captive Kangaroo Rats. Oecologia 24: 105-140.

Kennedy, M. L. and G. D. Schnell. 1978. Geographic variation and sexual dimorphism in Ord's Kangaroo Rat, Dipodomys ordii. J. Mammal. 59: 45-59.

Kenny, R. J. L. 1989. Population, distribution, habitat use, and natural history of Ord's Kangaroo Rat (Dipodomys ordii) in the sand hill areas of south-western Saskatchewan and south-eastern Alberta. Unpubl. M.Sc. 
thesis, University of Manitoba, Winnipeg, MB. 69 pp.

Kotler, B. P. 1985. Owl predation on desert rodents which differ in morphology and behavior. J. Mammal. 66: 824-828.

Kooyman, G. L. 1963. Milk analysis of the Kangaroo Rat, Dipodomys merriami. Science 147: 1467-1468.

Maxwell, M. H., and L. N. Brown. 1968. Ecological distribution of rodents on the high plains of eastern Wyoming. Southwest. Natur. 13: 143-158.

McCulloch, C. Y., and J. M. Inglis. 1961. Breeding periods of the Ord Kangaroo Rat. J. Mammal 42: 337-344.

Morton, S. R., D. S. Hinds, and R. E. MacMillen. 1980. Cheek pouch capacity in Heteromyid rodents. Oecologia 46: 143-146.

National Research Council. 1995. Science and the Endangered Species Act. National Academy Press, Washington, DC. 271 pp.

Nero, R. W. 1956. The Kangaroo Rat in Saskatchewan. Blue Jay 14: 3-4.

Nero, R. W., and R. W. Fyfe. 1956. Kangaroo Rat colonies found. Blue Jay 14: $107-110$.

O'Farrell, M. J. 1974. Seasonal activity patterns of rodents in a sagebrush community. J. Mammal. 55: 809-823.

Price, M. V., P. A. Kelly, and R. L.
Goldingay. 1994. Distances moved by Stephens' Kangaroo Rat (Dipodomys stephensi Merriam) and implications for conservation. J. Mammal. 75: 929-939.

Randall, J. A., and C. M. Stevens. 1987. Footdrumming and other anti-predator responses in the Bannertail Kangaroo Rat (Dipodomys spectabilis). Behav. Ecol. Sociobiol. 20: 187-194.

Reynolds, H. G. 1958. The ecology of the Merriam Kangaroo Rat (Dipodomys merriami Mearns) on the grazing lands of southern Arizona. Ecol. Monogr. 28: 111-127.

Reynolds, H. W., and H. J. Armbruster. 1971. Field investigations of the Suffield Military Reserve: progress report. Canadian Wildlife Service, Edmonton, AB. 12 pp.

Rogers, L. E., and J. D. Hedlund. 1980. A comparison of small mammal populations occupying three distinct shrub-steppe communities in eastern Oregon. Northwest Sci. 54: 183-186.

Rosenzweig, M. L. 1974. On the optimal aboveground activity of Bannertail Kangaroo Rats. J. Mammal. 55: 193-199.

Saskatchewan Conservation Data Centre. 1994. Vertebrate species tracking list. Saskatchewan Conservation Data Centre, Regina, SK. 5 pp.

Schmidt-Nielson, K. 1964. Desert animals: physiological problems of heat and water. Clarendon Press, London, 
UK. 277 pp.

Setzer, H. W. 1949. Subspeciation in the

Kangaroo Rat, Dipodomys ordii. University of Kansas, Museum of Natural History Publications 1: 473-573.

Smith, H. C. 1972. Some recent records of Alberta mammals. Blue Jay 30: 53-54.

Smith, H. C. 1993. Alberta mammals: an atlas and guide. Provincial Museum of Alberta, Edmonton, AB. 238 pp.

Smith, H. C., and M. J. Hampson. 1969. A Kangaroo Rat colony in Alberta. Blue Jay 27: 224-225.

Soper, J. D. 1964. The mammals of Alberta. Hamly Press, Edmonton, AB. $402 \mathrm{pp}$.

Stangl, F. B. Jr., T. S. Schafer, J. R. Goetze, and W. Pinchak. 1992. Opportunistic use of modified and disturbed habitat by the Texas Kangaroo Rat (Dipodomys elator). Texas J. Sci. 44: 25-35.

Stevens, W. 1972. Kangaroo Rats and rattlesnakes, 4th ed. Department of National Defence, Canadian Forces
Base Suffield, AB. 21 pp.

U.S. Fish and Wildlife Service. 1997. List of endangered and threatened wildlife. Division of Endangered Species, U.S. Fish and Wildlife Service, Special Reprint 50 CFR 17.11/17.12. Washington, DC. 30 pp.

Wallis, C., and C. Wershler. 1988. Rare wildlife and plant conservation studies in sandhill and sand plain habitats of southern Alberta. Unpubl. rept. for Alberta Forestry, Lands and Wildlife, Alberta Recreation and Parks, and World Wildlife Fund Canada, Edmonton, $\mathrm{AB}$.

Webster, D. B., and M. Webster. 1975. Auditory systems of Heteromyidae: functional morphology and evolution of the middle ear. J. Morphol. 146: 343-376.

Wright, H. A. and A. W. Bailey 1982. Fire ecology: United States and southern Canada. John Wiley and Sons, New York, NY. 501 pp.

Yousef, M. K., W. D. Robertson, and H. D. Johnson. 1970. Energy expenditure of running Kangaroo Rats Dipodomys merriami. Comp. Biochem. Physiol. 36: 387-393. 
APPENDIX 1. Definitions of selected legal and protective designations.

\section{A. Status of Alberta Wildlife color lists (after Alberta Wildlife Management Division 1996)}

\begin{tabular}{|l|l|}
\hline Red & $\begin{array}{l}\text { Current knowledge suggests that these species are at risk. These species have declined, or are } \\
\text { in immediate danger of declining, to nonviable population size }\end{array}$ \\
\hline Blue & $\begin{array}{l}\text { Current knowledge suggests that these species may be at risk. These species have undergone } \\
\text { non-cyclical declines in population or habitat, or reductions in provincial distribution }\end{array}$ \\
\hline Yellow & $\begin{array}{l}\text { Species that are not currently at risk, but may require special management to address concerns } \\
\text { related to naturally low populations, limited provincial distributions, or demographic/life history } \\
\text { features that make them vulnerable to human-related changes in the environment }\end{array}$ \\
\hline Green & $\begin{array}{l}\text { Species not considered to be at risk. Populations are stable and key habitats are generally } \\
\text { secure }\end{array}$ \\
\hline Undetermined & Species not known to be at risk, but insufficient information is available to determine status \\
\hline
\end{tabular}

\section{B. Alberta Wildlife Act}

Species designated as "endangered" under the Alberta Wildlife Act include those defined as "endangered" or "threatened" by A Policy for the Management of Threatened Wildlife in Alberta (Alberta Fish and Wildlife 1985):

\begin{tabular}{|l|l|}
\hline Endangered & A species whose present existence in Alberta is in danger of extinction within the next decade \\
\hline Threatened & $\begin{array}{l}\text { A species that is likely to become endangered if the factors causing its vulnerability are not } \\
\text { reversed }\end{array}$ \\
\hline
\end{tabular}

\section{Committee on the Status of Endangered Wildlife in Canada (after COSEWIC 1996)}

\begin{tabular}{|l|l|}
\hline Extirpated & A species no longer existing in the wild in Canada, but occurring elsewhere \\
\hline Endangered & A species facing imminent extirpation or extinction \\
\hline Threatened & A species likely to become endangered if limiting factors are not reversed \\
\hline Vulnerable & $\begin{array}{l}\text { A species of special concern because of characteristics that make it particularly sensitive to } \\
\text { human activities or natural events }\end{array}$ \\
\hline Not at Risk & A species that has been evaluated and found to be not at risk \\
\hline Indeterminate & A species for which there is insufficient scientific information to support status designation \\
\hline
\end{tabular}

\section{United States Endangered Species Act (after National Research Council 1995)}

\begin{tabular}{|l|l|}
\hline Endangered & Any species which is in danger of extinction throughout all or a significant portion of its range \\
\hline Threatened & $\begin{array}{l}\text { Any species which is likely to become an endangered species within the foreseeable future } \\
\text { throughout all or a significant portion of its range }\end{array}$ \\
\hline
\end{tabular}


APPENDIX 2. References for Ord's Kangaroo Rat occurrence records shown in Figure 1.

\begin{tabular}{|c|c|c|}
\hline $\begin{array}{l}\text { Site } \\
\text { Number }\end{array}$ & Details* & Source \\
\hline 1 & $\begin{array}{l}\text { T20 R2 W4 obs } \\
\text { T15 R5 W4, T15 R6 W4, T16 R5 W4, T16 R6 W4, } \\
\text { T17 R5 W4, T18 R4 W4, T18 R5 W4, T19 R3 W4, } \\
\text { T19 R4 W4, T20 R1 W4, T20 R2 W4, T20 R3 W4, } \\
\text { T20 R4 W4, T21 R1 W4 spec/obs } \\
\text { T18 R4 W4 spec } 56565657 \\
\text { C.F.B. Suffield obs } \\
\text { T20 R2 W4 spec } 5912591359145915591659195920 \\
\text { T22 R2 W4 spec } 8206\end{array}$ & $\begin{array}{l}\text { Alberta Wildlife Management Division } \\
\text { Gummer, unpubl. data } \\
\text { Reynolds and Armbruster (1971) } \\
\text { Stevens (1972) } \\
\text { University of Alberta Museum of Zoology }\end{array}$ \\
\hline 2 & $\begin{array}{l}\text { Middle Sand Hills obs } \\
\text { T20 R29 W3 obs } \\
\text { Burstall Sand Hills, Cramersburg Sand Hills, } \\
\text { Great Sand Hills obs }\end{array}$ & $\begin{array}{l}\text { Kenny (1989) } \\
\text { Baron (1979) } \\
\text { Kenny (1989) }\end{array}$ \\
\hline 3 & $\begin{array}{l}\text { T19 R2 W4 spec z70.53.72 z70.53.73 } \\
\text { T19 R1 W4 spec } 5911591759185500\end{array}$ & $\begin{array}{l}\text { Baron, pers. comm. } \\
\text { Provincial Museum of Alberta } \\
\text { Smith (1972) } \\
\text { University of Alberta Museum of Zoology }\end{array}$ \\
\hline 4 & $\begin{array}{l}\text { T20 R2 W4 spec z69.53.15 z69.53.16 z69.53.17 } \\
\text { z69.53.18 z69.53.19 z69.53.43 z69.53.44 z70.53.26 } \\
\text { z70.53.27 z70.53.28 z70.53.29 z70.53.74 z70.123.1 } \\
\text { z71.16.1 z72.80.1 }\end{array}$ & $\begin{array}{l}\text { Baron, pers. comm. } \\
\text { Provincial Museum of Alberta } \\
\text { Smith and Hampson (1969) }\end{array}$ \\
\hline 5 & $\begin{array}{l}\text { T20 R2 W4 spec 83.28.1 83.28.2 83.28.3 84.31.2 } \\
84.31 .384 .31 .484 .31 .584 .31 .684 .31 .784 .32 .184 .32 .2 \\
84.32 .384 .32 .4\end{array}$ & $\begin{array}{l}\text { Baron, pers. comm. } \\
\text { Provincial Museum of Alberta }\end{array}$ \\
\hline 6 & Medicine Hat spec & $\begin{array}{l}\text { Anderson (1946) } \\
\text { U.S. Biological Survey }\end{array}$ \\
\hline 7 & Dune Point obs & Wallis and Wershler 1988 \\
\hline 8 & $\begin{array}{l}\text { T12 R23 W3 spec } 6288628962906291 \\
\text { T20 R19 W3 spec T20 R24 W3 spec } \\
\text { T21 R22 W3 spec } 5982 \\
\text { T21 R28 W3 obs } \\
\text { T22 R24 W3 spec } 9281,14029, \text { M101 }\end{array}$ & $\begin{array}{l}\text { Baron, pers. comm. } \\
\text { Nero (1956) } \\
\text { Nero and Fyfe (1956) } \\
\text { Royal Saskatchewan Museum }\end{array}$ \\
\hline 9 & Ravenscrag obs & Carleton (1956) \\
\hline 10 & T13 R21 W3 spec & Anderson (1946) \\
\hline 11 & T18 R24 W3 spec T20 R22 W3 spec T15 R24 W3 obs & Epp and Waker (1980) \\
\hline
\end{tabular}

* obs $=$ observation record $(\mathrm{s})$, spec $=$ specimen $(\mathrm{s})$ collected, $\mathrm{T}=$ Township, $\mathrm{R}=\mathrm{Range}, \mathrm{W}=$ West of $\ldots$, numbers represent specimen records for the respective museums 


\section{List of Titles In This Series}

(as of September 1997)

No. 1 Status of the Piping Plover (Charadrius melodus) in Alberta, by David R. C. Prescott. 19 pp.

No. 2 Status of the Wolverine (Gulo gulo) in Alberta, by Stephen Petersen. $17 \mathrm{pp}$.

No. 3 Status of the Northern Long-eared Bat (Myotis septentrionalis) in Alberta, by M. Carolina Caceres and M. J. Pybus. 19 pp.

No. 4 Status of the Ord's Kangaroo Rat (Dipodomys ordii) in Alberta, by David L. Gummer. 16 pp.

No. 5 Status of the Eastern Short-horned Lizard (Phrynosoma douglassii brevirostre) in Alberta, by Janice D. James, Anthony P. Russell and G. Lawrence Powell. 20 pp.

No. 6 Status of the Prairie Rattlesnake (Crotalus viridis viridis) in Alberta, by Sheri M. Watson and Anthony P. Russell. 26 pp.

No. 7 Status of the Swift Fox (Vulpes velox) in Alberta, by Susan E. Cotterill. 17pp.

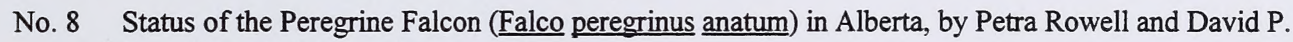
Stepnisky. In Preparation.

No. 9 Status of the Northern Leopard Frog (Rana pipiens) in Alberta, by Greg Wagner. In Preparation.

No. 10 Status of the Sprague's Pipit (Anthus spragueii) in Alberta, by David R. C. Prescott. 14 pp.

No. 11 Status of the Burrowing Owl (Speotyto cunicularia hypugaea) in Alberta, by Troy I. Wellicome. $21 \mathrm{pp}$. 


\section{NOTES}


National Library of Canada

Bional Library of Canada Bibliothèque nationale du Canada

3 3286513566899 